\title{
HANDBOOK
}

\section{OF CHURCH HISTORY}

Edited by HUBERT JEDIN and JOHN P. DOLAN.

A critical history of the Church combining lucid exposition with the highest historical scholarship.

Volume IV: From the High Middle Ages to the Eve of the Reformation

October 600 pp 140s net

Already published:

Volume I: From the Apostolic Community to Constantine

(90s net)

"A really readable piece of work ... superlatively well handled ... An outstanding product of the renewal of Church life and thought."-Michael Richards, S.T.L., B.Litt., in The Clergy Review

Volume III: The Church in the Age of Feudalism (120s net)

"Quite indispensable to any student seriously interested in the history of the Church during this period . . . All that readers familiar with Volume I will have come to expect: a mass of information and expert assessment ... excellent bibliographies, authoritative and up-to-date chapters by scholars each of leading stature in his field ... The Handbook is becoming the "Fliche-Martin" of our generation."-R. A. Markus in The Tablet

\section{A CONCISE HISTORY OF THE CHURCH \\ AUgust Franzen}

Revised and Edited by JOHN P. DOLAN

This very authoritative concise history of the Church takes the reader from earliest times up to the aggiornamento of the post-Vatican II Church (1965). Essential for all religious libraries. $480 \mathrm{pp} 65 \mathrm{~s}$ net

\section{Burns \& Oates}




\section{EASTERN CHURCHES REVIEW}

\author{
Editors:
}

GEORGE EVERY, SSM ROBERT MURRAY, S] KALLISTOS TIMOTHY WARE

Articles in Vol. 2, No. 3 include:

Eastern Orthodox Migration to Australia by Paul B. Anderson.

The Benedictine Monastery of St. Mary on Mount Athos by Dom Leo Bonsall.

Theosis in Later Byzantine Theology by Brother George Every SSM

The Russian Christian Philosophy of Man and Western Tradition by Elias Denissoff.

'Pray Without Ceasing': the Ideal of Continual Prayer in Eastern Monasticism by Kallistos Timothy Ware.

The See of Mark and its Contribution to the Universal Church by Paul Verghese.

Twice yearly. Single copy 10/Annual Subscription $\mathrm{El}$ to

E.C.R., 2 Coombe Lodge, Elliscombe Road, London, S.E.7

\section{The Journal of Ecclesiastical History}

\section{BACK VOLUMES}

Volumes XVII-XIX (1966-1968) are available from the London and New York offices of Cambridge University Press, price 60s. net $(\$ 10.00)$ each. Single parts of these volumes are available at 305 . net $(\$ 5.00)$ each.

Volumes I-XVI are available from Johnson Reprint Co. Ltd., Berkeley Square House, Berkeley Square, London WIX 6BA and Johnson Reprint Corporation, I I I Fifth Avenue, New York, N.Y. I 0003 .

\section{The Journal of Ecclesiastical History}

is one of the 47 learned journals published by Cambridge University Press.

A descriptive catalogue of Cambridge journals with details of back volumes is available from the London and New York offices of the Press.

Cambridge journals may be ordered from a bookseller or direct from the publishers.

\section{Cambridge University Press}

P.O. Box 92, London, N.W.1

32 East 57th Street, New York, N.Y. 10022 


\section{The Text of the New Testament}

Its Transmission, Corruption, and Restoration

\section{BRUCE M. METZGER}

This book supplies information concerning the science and the art of textual criticism as applied to the New

Testament. The second edition embodies references to more than 150 additional books and articles dealing with Greek manuscripts, early versions, and critical studies of recently discovered witnesses to the text of the New Testament.

Second edition 16 plates 4 figures 45/- net

\section{A Patristic Greek Lexicon}

Fascicle 5. Addenda et corrigenda

This fascicle completes the work. The five fascicles are available separately at 84/- net each, or in one volume at $£ 22$ net

\section{A Catalogue of Misericords in Great Britain}

\section{G. L. REMNANT}

with an Essay on their Iconography by M. D. ANDERSON Compiled from available records and personal visits. The illustrations have been selected to show not only well-known examples but also carvings of outstanding interest in smaller

\section{The Ecclesiastical History of Orderic Vitalis}

Volume II, Books III and IV

Edited and translated by MARJORIE CHIBNALL

The Historia Ecclesiastica of Orderic Vitalis has been called 'the greatest social history of the Middle Ages'. This volume includes an account of the early years of the Norman monastery of St. Evroul, to which he was sent as a child oblate, and a narrative of the Conquest of England and the Norman settlement up to 1075 . Frontispiece 90/-net (Oxford Medieval Texts)

\section{The Heritage of the Reformation}

\section{WILHELM PAUCK}

Dr. Pauck explores the teachings and experiences of Luther and Calvin, the spirit of the Reformation ministry, and the Catholic response to the Reformation, placing these against the problems of Protestant theology today. Second edition 23/6 net (Galaxy Books) (OUP New York)

\section{From Shadow to Promise}

\section{Old Testament Interpretation} from Augustine to the Young Luther

JAMES SAMUEL PREUS 72/- net (Harvard University Press)

\section{Two Churches}

England and Italy in the

Thirteenth Century

\section{ROBERT BRENTANO}

A comparison of two provincial churches of the thirteenth century. 8 plates

2 maps $£ 5 / 4 / 6$ net (Princeton University Press)

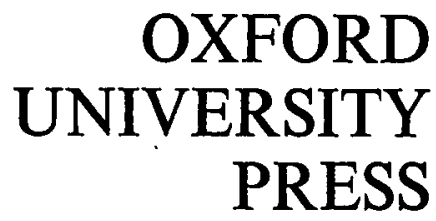




\section{The Royal Supremacy in the Elizabethan Church CLAIRE CROSS}

This book has a two-fold aim : to consider the theoretical extent of the royal supremacy in the Elizabethan Church and to see how far this supremacy was effective in practice. This discussion of religious and political issues will attract those interested in 16th Century history in general ; it is also intended for undergraduates studying Elizabethan history in depth and could well be used by those concentrating upon a special period within their ' $A$ ' level course.

Cloth 40s, Paperback 22s. Historical Problems : Studies and Documents.

\section{Allen \& Unwin}

\section{The Journal of Religious History}

\section{Volume 5, No. 3}

June 1969

\section{CONTENTS}

Articles

B. F. Harris: $\quad$ APOLLONIUS OF TYANA: FACT AND FICTION

Garry W. Trompf: FRIEDRICH MAX MULLER: SOME PRELIMINARY CHIPS FROM HIS GERMAN WORKSHOP

K. Elford: $\quad$ THE THEOLOGY OF CLERICAL PARTICIPATION. JOHN DUNMORE LANG AND DIRECT CLERICAL REPRESENTATION IN POLITICS

Keith R. Campbell: PRESBYTERIAN CONFLICTS IN NEW SOUTH WALES 1837-1865

Review Articles

G. S. R. Thomas: MARTYRDOM AND PERSECUTION IN THE EARLY CHURCH

Niel Gunson: THE THEOLOGY OF IMPERIALISM AND THE Book Reviews THE THEOLOGY OF IMPERIALISM AND THE
MISSIONARY HISTORY OF THE PACIFIC

Annual subscription \$A2.50; price per single copy \$A1.50

Sydney University Press, University of Sydney, Sydney, N.S.W., 2006 


\section{History}

AND

\section{Theory}

STUDIES IN

THE PHILOSOPHY

OF HISTORY

\section{Volume I- (1960- )}

Editor: George H. NADEL

Executive Editor:

Richano T. VANN

Edilorial Committee: RAyMOND ARon, IsALAH Berlin, Fernand Braudel, Simney Hook, Maurice Mandelbaum, A. D. Momigliano, John Passmore, W. H. Walse, C. Vann WOODWARD

History and Theory is the first international journal devoted to the philosophy of history. Monographs, essays, exchanges, roviews, and bibliographies are published in four areas: the theory of history; the method of history; historiography; and the relationship between problems in historical theory and method and those in economics, psychology, and other social sciences.

As one of the most important, vital, and comprehensive interdisciplinary journals of our time, it has elicited enthusiastic worldwide response.

Frequency: three numbers and a Beiheft per year.

Subscriptions: $\$ 6.00$ per year. Subscriptions accepted in advance for as many years as desired.

(Complete runs and individual back numbers also available. Write for more information.)

Send subscriptions to:

\section{WESLEYAN} UNIVERSITY PRESS

100 Riverview Center Middletown, Connecticut 06457
Cambridge Studies in Medieval Life and Thought, Second Series XIV The School of Peter Abelard

The Influence of Abelard's

Thought in the Early

Scholastic Period D. E. LUSCOMBE

Peter Abelard's public career was ended in 1140 by an ecclesiastical condemnation for heresy, but his thought touched upon central issues of the medieval scholastic movement and his teachings continued to be controversial.

Dr Luscombe discusses conflicting estimates of Abelard in the twelfth century and later and his influence on his contemporaries and successors. This is the last book in the second series of Cambridge Studies in Medieval Life and Thought under the general editorship of Dom David Knowles.

75s. net

\section{Catholic Theories of Biblical Inspiration, 1810 to the Present}

\section{A Review and Critique JAMES T. BURTCHAELL}

Fr Burtchaell traces the background of the controversy and the contribution of the leading Catholic theologians in Europe from the foundation of the Tübingen school in 1810 until the papal condemnation of 'Modernism' in 1907. He goes on to assess the effect of this condemnation on the course of the debate during the first half of this century and suggests that much of the present theorizing by Catholics on inspiration is only a hesitant presentation of ideas that were more boldly advanced by progressive thinkers a century ago.

70s. net

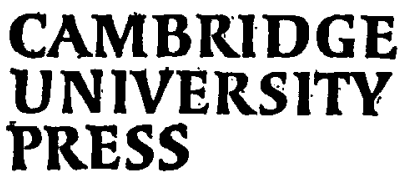




\section{The Spirit of the Counter-Reformation OUTRAM EVENNETT \\ Edited by JOHN BOSSY. \\ Foreword by Dom DAVID KNOWLES}

Isolates the special and positive characteristics of the Counter-Reformation, and accounts for them in relation to their environment. It is based on six lectures delivered by the late Outram Evennett as Birkbeck Lecturer in Cambridge in I95I. Dr Bossy has prepared them for publication and written a postscript analysing some of the problems raised since they were given.

'A brilliant and suggestive interpretation.' Church Times

35s. net

\section{The Great Church in Captivity}

A Study of the Patriarchate of Constantinople from the Eve of the Turkish Conquest to the Greek War of Independence

\section{SIR STEVEN RUNCIMAN}

'Sir Steven Runciman wraps tolerant and profound scholarship with elegance and moments of straight-faced humour ... uncovering from a vast store of reference much that will excite even specialists and allowing the amateur a broadly interesting story, together with much incidental and curious information ... A certain human warmth shines throughout.' The Times

\section{Elizabeth and the English Reformation}

\section{The Struggle for a Stable Settlement of Religion}

\section{WILLIAM P. HAUGAARD}

The early years of Elizabeth's reign set the direction of English religion after the Reformation. By centring his study on the Convocation of 1563 , Professor Haugaard reassesses the roles of queen and cleric as they schemed and fought to make the national Church conform to their own particular vision of an ideal Christianity.

\section{The Orthodox Church and Independent Greece, 1821-52}

\section{CHARLES A. FRAZEE}

A lively account of this formative period of modern Greek history, which concentrates on the constitutional relations between Church and state and the diplomatic activities of the three protecting powers, Protestant Britain, Roman Catholic France and Orthodox Russia. 


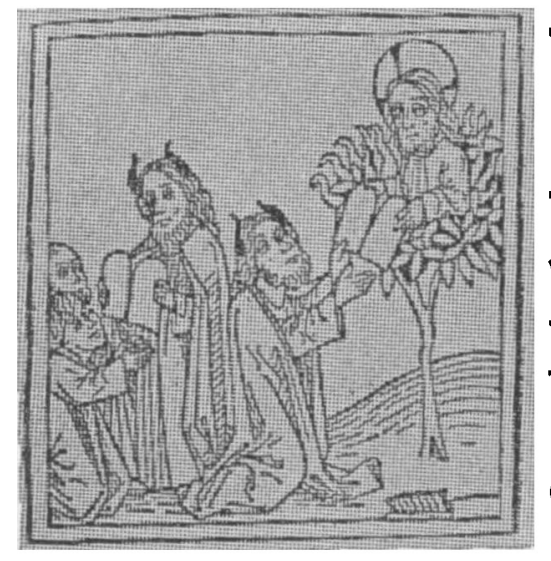

\title{
The Cambridge History of the Bible
}

\section{Volume 2: The West, from the Fathers to the Reformation}

\author{
Edited by \\ G. W. H. LAMPE
}

The Cambridge History of the Bible treats the Bible as the central document of Western civilization: a source of doctrine and of Church government, and an influence on education, on the growth of scholarship, and on art and literature, as well as on the liturgy and life of the Church. This volume covers the period from Jerome and the Fathers to the time of Erasmus. Each chapter is written by an expert on the subject, who summarizes existing knowledge and, in many cases, advances it by reporting his own research. 7os. net

\section{Religion in the Middle East}

\section{Two Volumes}

\section{General Editor: A. J. ARBERRY}

Subject Editors: DR E. I. J. ROSENTHAL (Judaism), CANON M. A. C. WARREN (Christianity), PROFESSOR C. F. BECKINGHAM (Islam)

'Among the factors dividing and, to a certain extent, uniting the peoples of the Middle East, not the least interesting and noteworthy are the religions they variously profess and the sects within each religion by which they are further fragmented.'

Volume I studies Judaism and Christianity; Volume II Islam, and their relationship with each other in concord and in conflict, during the last hundred years. The contributors also discuss the interaction of ethnic, economic, political, social and cultural factors to help a fuller understanding of the contemporary religious situation.

Volume 1; 608 pages; 14 plates; 13 maps

Volume 2; 762 pages; 16 plates; 12 maps

£7 net the set

\section{CAMBRIDGE UNIVERSITY PRESS}

